\title{
PRESTASI KERJA : PENILAIAN KERJA KARYAWAN DAN KEPUASAN KERJA
}

(Studi Kasus pada PT Mitrapak Eramandiri Cabang Cikarang)

\author{
Erina Rulianti \\ STIE PELITA BANGSA \\ erina.rulianti@pelitabangsa.ac.id
}

\begin{abstract}
ABSTRAK
Tujuan penelitian ini yaitu untuk menguji pengaruh penilaian kinerja karyawan dan kepuasan kerja terhadap prestasi kerja karyawan. Penelitian ini merupakan penelitian deskriptif dengan pendekatan kuantitatif yang dilaksanakan di PT. Mitrapak Eramandiri Cabang Cikarang. Populasi penelitian ini adalah seluruh karyawan PT. Mitrapak Eramandiri Cabang Cikarang yang berjumlah 134 karyawan dengan sampel 57 karyawan. Teknik pengambilan sampel adalah random sampling. Teknik pengumpulan data menggunakan observasi, studi pustaka dan kuisioner. Teknik analisis data yang digunakan adalah uji validitas, uji reliabilitas, analisis linier regresi berganda, koefisien determinasi $\left(\mathrm{r}^{2}\right)$ dan uji hipotesis. Berdasarkan data analisis, persamaan regresi yang diperoleh adalah sebagai berikut: $\mathrm{Y}=0,759+0,463(\mathrm{X} 1)+$ 0,274 ( X2). Berdasarkan pengujian hipotesis menggunakan uji t (parsial) bahwa penilaian kinerja karyawan serta kepuasan kerja berpengaruh positif dan signifikan terhadap prestasi kerja karyawan. Hasil uji f (simultan) menunjukan bahwa penilaian kinerja karyawan dan kepuasan kerja berpengaruh positif dan signifikan terhadap prestasi kerja karyawan. Nilai adjust $R$ square sebesar adalah 0,384 atau sebesar $38,4 \%$. Sedangkan sisanya sebesar $61,6 \%$ dipengaruhi oleh variabel lain yang tidak dimasukkan atau tidak dibahas dalam penelitian ini.
\end{abstract}

Kata kunci : Penilaian Kinerja Karyawan, Kepuasan Kerja, Prestasi Kerja

ABSTRACT

The purpose of this study is to examine the effect of employee performance appraisal and job satisfaction on employee performance. This research is a descriptive research with quantitative approach implemented in PT. Mitrapak Eramandiri Branch Cikarang. The population of this research is all employees of PT. Mitrapak Eramandiri Branch Cikarang which amounted to 134 employees with a sample of 57 employees. The sampling technique is random sampling. Data collection techniques used observation, literature study and questionnaire. Data analysis technique used is test validity, reliability test, linear regression analysis, coefficient of determination $\left(r^{2}\right)$ and hypothesis test. Based on the data analysis, the regression equation obtained is as follows: $Y=0.759+0.463(X 1)+0.274(X 2)$. Based on the hypothesis testing using $t$ test (partial) that the assessment of employee performance and job 
satisfaction have a positive and significant impact on employee performance. Result of test $f$ (simultan) showed that employee performance appraisal and job satisfaction have positive and significant influence to employee performance. Adjusted $R$ square value is 0.384 or $38.4 \%$. While the rest of $61.6 \%$ influenced by other variables that are not included or not discussed in this study.

\section{Keywords: Employee Performance Appraisal, Job Satisfaction, Employees' Performance}

\section{PENDAHULUAN}

Sumber daya manusia merupakan salah satu penggerak utama bagi setiap operasi perusahaan, tujuan memahami dan mempelajari menajemen sumber daya manusia adalah sebagai pengetahuan yang diperlukan untuk memiliki kemampuan analisa dalam menghadapi masalah-masalah manajemen khususnya dibidang organisasi. Sumber daya manusia dalam suatu perusahaan memegang peranan penting dalam menentukan maju tidaknya suatu perusahaan, artinya jika suatu perusahaan memiliki sumber daya manusia yang berkualitas maka perusahaan tersebut akan maju dan mampu bersaing dengan perusahaan lain dan sebaliknya jika suatu perusahaan tidak memiliki sumber daya manusia yang berkualitas maka perusahaan tersebut sulit untuk maju dan bersaing dengan perusahaan lain (Putri, N. dan Zulkarnia, A., 2015).

Sebagai salah satu faktor penentu keberhasilan dalam mencapai tujuan perusahaan, maka perusahaan harus memiliki karyawan yang berkualitas. Terutama saat ini, seluruh perusahaan dituntut untuk meningkatkan produktivitas, kreativitas dan perfomance yang tinggi agar mampu menghadapi persaingan yang semakin ketat. Hal ini berkaitan dengan cara pemeliharaan perusahaan terhadap prestasi kerja karyawannya. Untuk mengoptimalkan karyawan dalam menjalankan tugas dan tanggung jawab yang telah diberikan, agar proses tersebut berjalan lancar dan seimbang maka diperlukan suatu penilaian kinerja dan kepuasan kerja karyawan yang menjadi salah satu faktor pendorong meningkatnya prestasi kerja karyawan (Wahyuningsih,E.P.,2012). Untuk meningkatkan kinerja produktivitas karyawan, perusahaan perlu memikirkan bagaimana cara untuk mengontrol para karyawannya. Salah satu cara yang harus dilakukan ialah melakukan evaluasi kinerja dengan menggunakan sistem penilaian yang dilakukan secara berkala.

Penilaian kinerja karyawan dapat dilihat melalui proses kerja. Proses kerja ini dapat menggambarkan karyawan yang memiliki kepuasan kerja dan juga memiliki keinginan untuk berprestasi dalam bekerja. Penilaian kinerja merupakan bagian terpenting dari seluruh proses kegiatan pegawai yang bersangkutan. Menurut Sedarmayanti (2011:261), mengemukakan bahwa penilaian kinerja adalah sistem formal untuk memeriksa/mengkaji dan mengevaluasi secara berkala kinerja seseorang. Dari hasil penilaian dapat dilihat kinerja perusahaan yang dicerminkan oleh kinerja karyawan karena kinerja 
merupakan perilaku nyata yang ditampilkan setiap orang sebagai prestasi kerja yang dihasilkan oleh karyawan sesuai dengan perannya dalam perusahaan. Apabila karyawan mengalami penurunan dalam kualitas kerja sehingga mempengaruhi penilaian kinerja, maka perusahaan harus menaruh perhatian lebih terhadap penilaian kinerja karyawan agar tujuan perusahaan tercapai sesuai dengan yang diinginkan (Wahyuningsih,E.P.,2012).

Penilaian kinerja menjadi suatu pedoman dalam bidang personalia yang diharapkan dapat menunjukan kepuasan kerja para karyawan secara rutin dan teratur. Menurut Wibowo (2011: 501) yaitu kepuasan kerja adalah derajat positif atau negatifnya perasaan seseorang mengenai berbagai segi tugas-tugas pekerjaan, tempat kerja dan hubungan dengan sesama pekerja. Ketidakpuasan kerja karyawan akan menimbulkan berbagai macam masalah seperti kecenderungan karyawan yang berhenti bekerja, sering absen dan berbagai pelanggaran kedisiplinan yang terkait dengan ketidakpuasan kerja sehingga menurunkan prestasi kerja karyawan. Dari segi karyawan, ketidakpuasan kerja dapat menyebabkan tidak semangatnya dalam bekerja, kelelahan bekerja, malas bekerja, dll (Wahyuningsih,E.P.,2012). Penilaian individu terhadap posisi sekarang dan merasa tidak puas dapat memicu seseorang untuk mencari pekerjaan lain akan tetapi bila karyawan merasakan kepuasan kerja maka akan menjadi pendorong prestasi kerja karyawan, karena kepuasan kerja menjadi salah satu faktor pendorong prestasi kerja karyawan (Suprihatiningrum, H. dan Bodroastuti, T., 2012). Dengan kepuasan kerja yang diperoleh, diharapkan kinerja yang tinggi dapat dicapai karyawan sehingga penilaian kinerja karyawan serta prestasi kerja bisa tercapai sesuai dengan tujuan perusahaan.

Prestasi kerja karyawan pada dasarnya adalah hasil kerja karyawan selama periode tertentu dibandingkan dengan standar, target atau kriteria yang telah ditentukan. Prestasi kerja menurut Hasibuan (2008:94) adalah prestasi kerja adalah suatu hasil kerja yang dicapai seseorang dalam melaksanakan tugas-tugas yang dibebankan kepadanya yang didasarkan atas kecakapan, pengalaman, dan kesungguhan serta waktu. Dalam organisasi atau perusahaan, memperhatikan prestasi kerja karyawan merupakan suatu yang sangat penting untuk dilakukan. Apabila prestasi kerja karyawan kurang mendapat perhatian, maka akan berdampak terjadinya penurunan prestasi kerja karyawan yang nanti akan berakibat terjadinya hal-hal yang tidak diinginkan oleh perusahaan. Penurunan prestasi kerja tidak boleh dibiarkan terus berlanjut, karena akan menyebabkan perusahaan mengalami kerugian. Maka dari itu, perusahaan perlu memperhatikan faktor-faktor pendorong untuk meningkatkan prestasi kerja pada karyawannya. Faktor yang mendorong prestasi kerja dalam hal ini adalah penilaian kinerja karyawan serta kepuasan kerja karyawan (Putri, N. dan Zulkarnia, A., 2015).

PT. Mitrapak Eramandiri Cabang Cikarang merupakan perusahaan manufakturing dibidang kosmetika berdiri sejak tahun 2008 berdasarkan permintaan PT Unilever Indonesia, Tbk yang melayani jasa pembuatan produkproduk perawatan kulit (kosmetika). PT. Mitrapak Eramandiri Cabang Cikarang merupakan salah satu contoh perusahaan yang melakukan penilaian kinerja pada karyawannya rutin satu tahun sekali yaitu pada bulan Desember. Pada periode 
penilaian kinerja karyawan di tahun 2016, PT. Mitrapak Eramandiri Cabang Cikarang mengalami penurunan prestasi kerja karyawan sehingga ada enam karyawan yang mendapatkan mutasi kerja. Hal ini didukung dengan wawancara dengan Ibu Ratri selaku Manajer bagian Human Resource and Development (HRD) pada tanggal 24 Maret 2017, beliau mengatakan bahwa periode penilaian kinerja karyawan di tahun 2016 mengalami penurunan kualitas kerja karyawan dan kurang merasakan kepuasan dalam bekerja yang menyebabkan penurunan prestasi kerja karyawan sehingga enam orang karyawan di mutasi ke bagian lain. Selain itu, menurut hasil wawancara dengan bagian yang di mutasi diperusahaan tersebut menjelaskan bahwa mereka kurang senang dengan beban kerja (target) yang terlalu tinggi serta kurang nyaman dengan rekan kerja.

Penelitian yang terkait dengan variabel kepuasan kerja serta prestasi kerja karyawan yakni penelitian yang dilakukan oleh Rina Milyati Yuniastuti (2011) yang berjudul "Analisis Pengaruh Kepuasan Kerja Terhadap Prestasi Kerja Karyawan Pada CV. Organik Agro System Di Bandar Lampung”. Penelitian ini menyimpulkan bahwa hasil perhitungan diperoleh koefisien korelasi product moment rxy $=0,815$, ini menunjukan bahwa kepuasan kerja mempunyai hubungan yang sangat kuat dan positif dengan prestasi kerja karyawan, koefisien determinasi $=66,40 \%$, ini menunjukan bahwa kepuasan kerja memberikan pengaruh sebesar $66,40 \%$ terhadap prestasi kerja karyawan dan sebesar 33,60\% dipengaruhi oleh faktor lain yang tidak dibahas oleh peneliti.

Sehubungan dengan uraian di atas penulis tertarik untuk mengadakan penelitian dengan judul "Pengaruh Penilaian Kinerja Karyawan Dan Kepuasan Kerja Terhadap Prestasi Kerja Karyawan Pada PT. Mitrapak Eramandiri Cabang Cikarang."

Tujuan penelitian ini diantaranya yaitu : 
1. Untuk mengetahui apakah ada pengaruh penilaian kinerja terhadap prestasi kerja pada karyawan di PT. Mitrapak Eramandiri Cabang Cikarang.

2. Untuk mengetahui apakah ada pengaruh kepuasan kerja terhadap prestasi kerja pada karyawan di PT. Mitrapak Eramandiri Cabang Cikarang.

3. Untuk mengetahui apakah ada pengaruh penilaian kinerja dan kepuasan kerja terhadap prestasi kerja pada karyawan di PT. Mitrapak Eramandiri Cabang 
Cikarang.

\section{MANAJEMEN SUMBER DAYA MANUSIA, PENILAIAN KERJA KARYAWAN, KEPUASAN DAN PRESTASI KERJA}

\section{Manajemen Sumber Daya Manusia}

Sumber daya manusia kini makin berperan besar bagi kesuksesan suatu organisasi. Banyak organisasi menyadari bahwa unsur manusia dalam suatu organisasi dapat memberikan keunggulan bersaing. Oleh karena itu, sumber daya manusia merupakan salah satu unsur paling vital bagi organisasi (Ike Kusdyah Rachmawati: 2008). Manajemen sumber daya manusia adalah suatu proses penangani berbagai masalah pada ruang lingkup karyawan, pegawai, buruh, manajer dan tenaga kerja lainnya untuk dapat menunjang aktifitas organisasi atau perusahaan demi mencapai tujuan yang telah ditentukan. Bagian atau unit yang biasanya mengurusi sdm adalah departmen sumber daya manusia atau human resourse department (HRD). Menurut A.F. Stiner, manajemen sumber daya manusia adalah suatu prosedur yang berkelanjutan yang bertujuan untuk memasok suatu organisasi atau perusahaan dengan orang-orang yang tepat untuk ditempatkan pada posisi dan jabatan yang tepat pada saat organisasi memerlukannya (Asep Tapip Yani: 2011).

\section{Penilaian Kinerja Karyawan}

Penilaian kinerja merupakan faktor kunci dalam mengembangkan potensi pegawai secara efektif dan efisien karena adanya kebijakan atau program yang lebih baik atas sumber daya manusia yang ada di dalam suatu organisasi. Penilaian kinerja individu sangat bermanfaat bagi pertumbuhan organisasi secara keseluruhan. Menurut Sedarmayanti (2011:261), mengemukakan bahwa penilaian kinerja adalah sistem formal untuk memeriksa/mengkaji dan mengevaluasi secara berkala kinerja seseorang.

Setiap perusahaan atau organisasi harus dapat menyediakan suatu sarana untuk menilai kinerja karyawan dan hasil penilaian dapat dipergunakan sebagai informasi pengambilan keputusan manajemen tentang kenaikan gaji/upah, penguasaan lebih lanjut, peningkatan kesejahteraan karyawan dan berbagai hal penting lainnya yang dapat mempengaruhi karyawan dalam melaksanakan pekerjaannya. Penilaian kinerja karyawan jika dikerjakan dengan benar, hal ini akan memberikan manfaat yang penting bagi karyawan yang dinilai, penilai, dan departemen kepegawaian, serta organisasi. Penilaian kinerja karyawan harus dilakukan untuk mengetahui prestasi yang dapat dicapai setiap karyawan. Apakah prestasi yang dicapai setiap karyawan baik, sedang, atau kurang. Penilaian prestasi penting bagi setiap karyawan dan berguna bagi organisasi untuk mengambil keputusan dan menetapkan tindakan kebijaksanaan selanjutnya (Wahyuningsih,E.P.,2012).

\section{Manfaat Dan Tujuan Penilaian Kinerja Karyawan}


Menurut Werther dan Davis dalam buku Manajemen SDM dalam Organisasi Publik dan Bisnis (Suwanto, et al, 2011:196) penilain kinerja mempunyai beberapa tujuan dan manfaat bagi perusahaan dan karyawan yang dinilai antar lain:

1. Performance Improvement.

Memungkinkan karyawan dan manajer untuk mengambil tindakan yang berhubungan dengan peningkatan kinerja.

2. Compensation Adjustment.

Membantu para pengambil keputusan untuk menentukan siap saja yang berhak menerima kenaikan gaji atau sebaliknya.

3. Placement decision.

Menentukan promosi, transfer dan demotion.

4. Training and Development Needs.

Mengevaluasi kebutuhan pelatihan dan pengembangan bagi karyawan agar kinerja mereka lebih optimal.

5. Career Planning and development.

Memandu unutk menentukan jenis karir dan potensi yang dapat dicapai.

6. Staffing Process Deficiencies.

Mempengaruhi prosedur perekrutan karyawan.

7. Information Innacuracies and Job-Design Errors.

Mengetahui ketidaktepatan informasi dan kesalahan perancangan pekerjaan.

8. Equal Employment Opportunity.

Kesempatan yang sama dalam pekerjaan.

9. External Challenges.

Tantangan-tantangan eksternal.

10. Feedback.

Umpan balik bagi karyawan dan perusahaan.

\section{Faktor Yang Mempengaruhi Penilaian Kinerja Karyawan}

Menurut Mondy (2008: 259) bahwa terdapat banyak faktor yang mempengaruhi penilaian kinerja, baik faktor internal maupun faktor eksternal. Faktor eksternal misalnya legislasi hukum yang mewajibkan sistem-sistem penilaian kinerja tidak bersifat diskriminatif, serikat pekerja yang menekankan senioritas sebagai dasar kenaikan gaji dan promosi. Sedangkan faktor internal misalnya budaya perusahaan yang dapat menjadi faktor penghambat atau faktor pendukung dalam penilaian kinerja.

\section{Indikator Penilaian Kinerja Karyawan}

Menurut Hasibuan (2012) salah satu indikator yang dapat dijadikan gambaran kinerja seorang karyawan dari ukuran yang dinilai secara tangible (kualitas, kuantitas, waktu) dan intangible (sasaran yang tidak dapat ditetapkan alat ukur atau standar) adalah sebagai berikut : 
1. Kesetiaan : Mencerminkan kesediaan karyawan menjaga dan membela organisasi di dalam maupaun di luar pekerjaan.

2. Kualitas dan kuantitas kerja : Merupakan hasil kerja baik kualitas maupun kuantitas yang dapat dihasilkan karyawan tersebut dari uraian pekerjaannya.

3. Kejujuran : Kejujuran dalam melaksanakan tugas-tugas memenuhi perjanjian baik bagi diri sendiri maupun orang lain.

4. Kedisiplinan : Mencerminkan kepatuhan karyawan dalam mematuhi peraturan yang ada dalam melakukan pekerjaan sesuai dengan instruksi yang diberikan kepadanya.

5. Kreativitas : Kemampuan karyawan dalam mengembangkan kreativitasnya untuk menyelesaikan pekerjaanya, sehingga lebih berdaya guna dan hasil guna.

6. Kerjasama : Kesediaan karyawan berprestasi dan bekerja sama dengan karyawan lain secara vertikal dan horizontal didalam maupun diluar pekerjaannya.

7. Kepemimpinan : Merupakan kemampuan untuk memimpin, berpengaruh, mempunyai pribadi yang kuat, dihormati, berwibawa dan dapat memotivasi orang lain atau bawahan untuk bekerja secara efektif.

8. Kepribadian : Sikap perilaku, kesopanan, periang, memberikan kesan yang menyenangkan, memperhatikan sikap yang baik, serta berpenampilan simpatik dan wajar.

9. Prakarsa : Kemapuan berpikir yang original dan berdasarkan inisiatif sendiri unutk menganalisis, menilai, menciptakan, memberikan alasan dan mendapatkan kesimpulan penyelesaian masalah yang dihadapinya.

10. Kecakapan : Merupakan kecakapan karyawan dalam menyatukan dan menyelaraskan bermacam-macam elemen yang semuanya terlibat didalam penyusunan kebijakan dan di dalam situasi manajemen.

11. Tanggung jawab : Kesediaan karyawan dalam mempertanggungjawabkan kebijaksanaannya, dan hasil kerjaanya, sarana dan prasarana yang digunakan, serta perilaku kerjanya.

\section{Kepuasan Kerja}

Kepuasan kerja adalah tingkat kesenangan yang dirasakan seseorang atas peranan atau pekerjaannya dalam organisasi. Tingkat rasa puas individu bahwa mereka mendapat imbalan yang setimpal dari bermacam-macam aspek situasi pekerjaan dari organisasi tempat mereka bekerja. Menurut Malayu S.P Hasibuan ( 2008 : 202 ) kepuasan kerja adalah sikap emosional yang menyenangkan dan mencintai pekerjaannya. Menurut Wibowo (2011: 501) yaitu kepuasan kerja adalah derajat positif atau negatifnya perasaan seseorang mengenai berbagai segi tugas-tugas pekerjaan, tempat kerja dan hubungan dengan sesama pekerja.

Kepuasan kerja karyawan sangat mempengaruhi kinerja dan produktivitas. Tingkat kepuasan kerja merupakan salah satu faktor yang 
mempengaruhi prestasi kerjanya karena yang akhirnya berpengaruh pada efektivitas organisasi. Dan juga kepuasan kerja karyawan tidak cukup hanya diberikan insentif saja akan tetapi karyawan juga membutuhkan motivasi, pengakuan dari atasan atas hasil pekerjaannya, situasi kerja yang tidak monoton dan adanya peluang untuk berinisiatif dan berkreasi (Suprihatiningrum, H. dan Bodroastuti, T., 2012).

\section{Faktor-Faktor Yang Mempengaruhi Kepuasan Kerja}

Menurut Anwar Prabu Mangkunegara (2011 : 118) ada dua faktor yang dapat mempengaruhi kepuasan kerja yaitu :

1. Faktor pegawai, yaitu kecerdasan (IQ), kecakapan khusus, umur, jenis kelamin, kondisi fisik, pendidikan, pengalaman kerja, masa kerja, kepribadian, emosi, cara berfikir dan sikap kerja.

2. Faktor pekerjaan, yaitu jenis pekerjaan, struktur organisasi, pangkat (golongan), kedudukan, mutu pengawasan, jaminan finansial, kesempatan promosi jabatan, interaksi sosial dan hubungan kerja.

\section{Indikator Kepuasan Kerja}

Menurut Malayu S.P Hasibuan ( 2008 : 202 ) kepuasan kerja adalah sikap emosional yang menyenangkan dan mencintai pekerjaanya. Sikap ini di cerminkan oleh moral kerja, kedisiplinan, dan prestasi kerja.

Berdasarkan definisi diatas, indikator kepuasan kerja adalah :

1. Menyenangi pekerjaannya

Kepuasan kerja yang dimiliki dan dirasakan seseorang diwujudkan dengan adanya gairah dalam dirinya untuk menyambut tugas-tugas yang akan dibebankan kepadanya dengan perasaan senang.

2. Mencintai pekerjaannya

Perasaan mencintai pekerjaan akan membuat seseorang dapat bekerja dengan lebih efektif dan efisien karena keinginan bekerja itu timbul dari dalam diri seseorang itu sendiri, sehingga tanpa pengawasan yang ketatpun orang tersebut dapat bekerja dengan disiplin

3. Moral kerja

Kesepakatan batiniah yang muncul dari dalam diri seseorang atau sekelompok orang untuk mencapai tujuan tertentu sesuai yang ditetapkan organisasi.

4. Kedisiplinan

Mencerminkan kepatuhan karyawan dalam mematuhi peraturan yang ada dalam melakukan pekerjaan sesuai dengan instruksi yang diberikan kepadanya.

5. Prestasi kerja 
Hasil kerja secara kualitas dan kuantitas yang dicapai oleh seorang karyawan dalam melaksanakan tugasnya sesuai dengan tanggung jawab yang diberikan kepadanya

\section{Prestasi Kerja Karyawan}

Prestasi kerja merupakan perwujudan dari hasil kerja seseorang yang akan menentukan perkembangan kariernya pada masa yang akan datang. Prestasi kerja menurut Malayu S.P. Hasibuan (2008 : 94) adalah suatu hasil kerja yang dicapai seseorang dalam melaksanakan tugas-tugas yang dibebankan kepadanya yang didasarkan atas kecakapan dan kesungguhan serta waktu. Berdasarkan uraian di atas dapat diketahui bahwa pengertian prestasi kerja karyawan yaitu kemampuan seseorang untuk menyelesaikan pekerjaan yang diberikan kepadanya denggan kesungguhan dan ketetapan waktu serta pengalaman yang ia miliki sehingga dapat menghasilkan sesuatu yang positif yang dapat menentukan perkembangan kariernya di masa yang akan datang (Wahyuningsih,E.P.,2012).

\section{Faktor-Faktor Yang Mempengaruhi Pencapaian Prestasi Kerja}

Prestasi kerja banyak dipengaruhi oleh banyak faktor-faktor yang dalam pekerjaannya itu sendiri, faktor-faktor tersebut meliputi : gaji atau upah, pengakuan hubungan antar pribadi, kondisi kerja dan sebagainya. Oleh karenanya untuk meningkatkan prestasi kerja karyawan dapat meningkatkan prestasi kerja karyawan dapat dilakukan dengan memperbaiki dan meningkatkan faktor-faktor tersebut. Faktor - faktor yang mempengaruhi prestasi kerja menurut Mangkunegara, Anwar Prabu (2011 : 67) ada dua faktor yang mempengaruhi pencapaian prestasi kerja, yaitu faktor kemampuan (ability) dan faktor motivasi (Motivation).

1. Faktor Kemampuan (ability)

Secara psikologis, kemampuan (ability) pegawai terdiri dari kemampuan potensi (IQ) dan kemampuan (Knowledge + Skill). Artinya, karyawan yang memiliki IQ diatas rata-rata (IQ 110-120) dengan pendidikan yang memadai untuk jabatannya dan terampil dalam mengerjakan pekerjaan sehari-hari, maka ia akan lebih mudah mencapai kinerja yang diharapkan.

2. Faktor Motivasi (Motivation)

Motivasi tumbuh dari sikap (attitude) seorang karyawan yang menghadapi situasi (situation) kerja. Motivasi merupakan kondisi yang menggerakkan diri pegawai yang terarah untuk mencapai tujuan perusahaan.

Sedangkan menurut Handoko,T. Hani (2008 : 193) : "Bahwa ada beberapa faktor yang mempengaruhi prestasi kerja karyawan. Karyawan bekerja produktif atau tidak tergantung pada motivasi, kepuasan kerja, tingkat stres, kondisi fisik pekerjaan, sistem kompensasi, desain pekerjaan dan aspek - aspek ekonomis, teknis serta keprilakuan lainnya". 


\section{Indikator Penilaian Prestasi Kerja}

Unsur-unsur yang dinilai dalam penilaian prestasi kerja karyawan dalam suatu perusahaan bermacam-macam tergantung penetapan perusahaan itu sendiri, tetapi pada umumnya indikator penilaian prestasi kerja menurut A. P. Mangkunegara (2009 : 67), menjelaskan bahwa prestasi kerja adalah hasil kerja secara kualitas dan kuantitas yang dicapai oleh seseorang pegawai dalam melaksanakan tugasnya sesuai dengan tanggung jawab yang diberikan kepadanya.

Dari definisi diatas, indikator prestasi kerja yaitu :

1. Kualitas

Mutu hasil kerja yang didasarkan pada standar yang ditetapkan. Biasanya diukur melalui ketepatan, ketelitian, ketrampilan, kebersihan hasil kerja

2. Kuantitas

Banyaknya hasil kerja sesuai dengan waktu kerja yang ada, yang perlu diperhatikan bukan hasil rutin tetapi seberapa cepat pekerjaan dapat diselesaikan.

3. Pelaksanaan tugas

Kewajiban karyawan melakukan aktivitas atau kegiatan yang berhubungan dengan pekerjaan yang ditugaskan perusahaan.

4. Tanggung jawab

Suatu akibat lebih lanjut dari pelaksanaan peranan, baik peranan itu merupakan hak dan kewajiban ataupun kekuasaan.

\section{Hipotesis Penelitian}

Bersadarkan kaitannya dengan penilaian kinerja karyawan dan kepuasan kerja terhadap prestasi kerja karyawan di atas, maka perkiraan/dugaan hipotesis pada penelitian ini sebagai berikut:

$\mathrm{Hi}_{1}$ : Diduga terdapat pengaruh penilaian kinerja karyawan sebagai variabel bebas (X1) terhadap prestasi kerja sebagai variabel terikat (Y).

$\mathrm{Hi}_{2}$ : Diduga terdapat pengaruh kepuasan kerja sebagai variabel bebas (X2) terhadap prestasi kerja sebagai variabel terikat (Y).

$\mathrm{Hi}_{3}$ : Diduga terdapat pengaruh penilaian kinerja karyawan sebagai variabel bebas (X1) dan kepuasan kerja sebagai variabel bebas (X2) berpengaruh positif dan signifikan terhadap prestasi kerja sebagai variabel terikat (Y).

\section{METODE PENELITIAN}

\section{Jenis Penelitian}

Penelitian ini merupakan penelitian deskriptif dengan menggunakan pendekatan kuantitatif. Metode penelitian kuantitatif, sebagaimana ditemukan 
oleh Sugiyono (2012:8) yaitu metode penelitian yang berlandaskan pada filsafat positivisme, digunakan untuk meneliti pada populasi atau sampel tertentu, pengumpulan data menggunakan instrumen penelitian, analisis data bersifat kuantitatif/statistik, dengan tujuan untuk menguji hipotesis yang ditetapkan. Menurut Sugiyono (2014:13) penelitian deskriptif yaitu penelitian untuk mengetahui nilai variabel mandiri, baik satu variabel atau lebih (independen) tanpa membuat perbandingan, atau menghubungkan variabel yang lain.

Data yang digunakan dalam penelitian ini dilakukan dengan mengumpulkan data atau informasi berupa data primer dan data sekunder. Adapun data primer dapat diperoleh dengan melakukan pengamatan langsung di lapangan, serta melalui hasil pengisian kuesioner. Sedangkan data sekunder diperoleh dari arsip data perusahaan dan berbagai literatur, baik berupa buku yang memuat teori-teori, hasil penelitian terdahulu, serta pencatatan data-data yang sudah ada di perusahaan.

\section{Disain Penelitian}

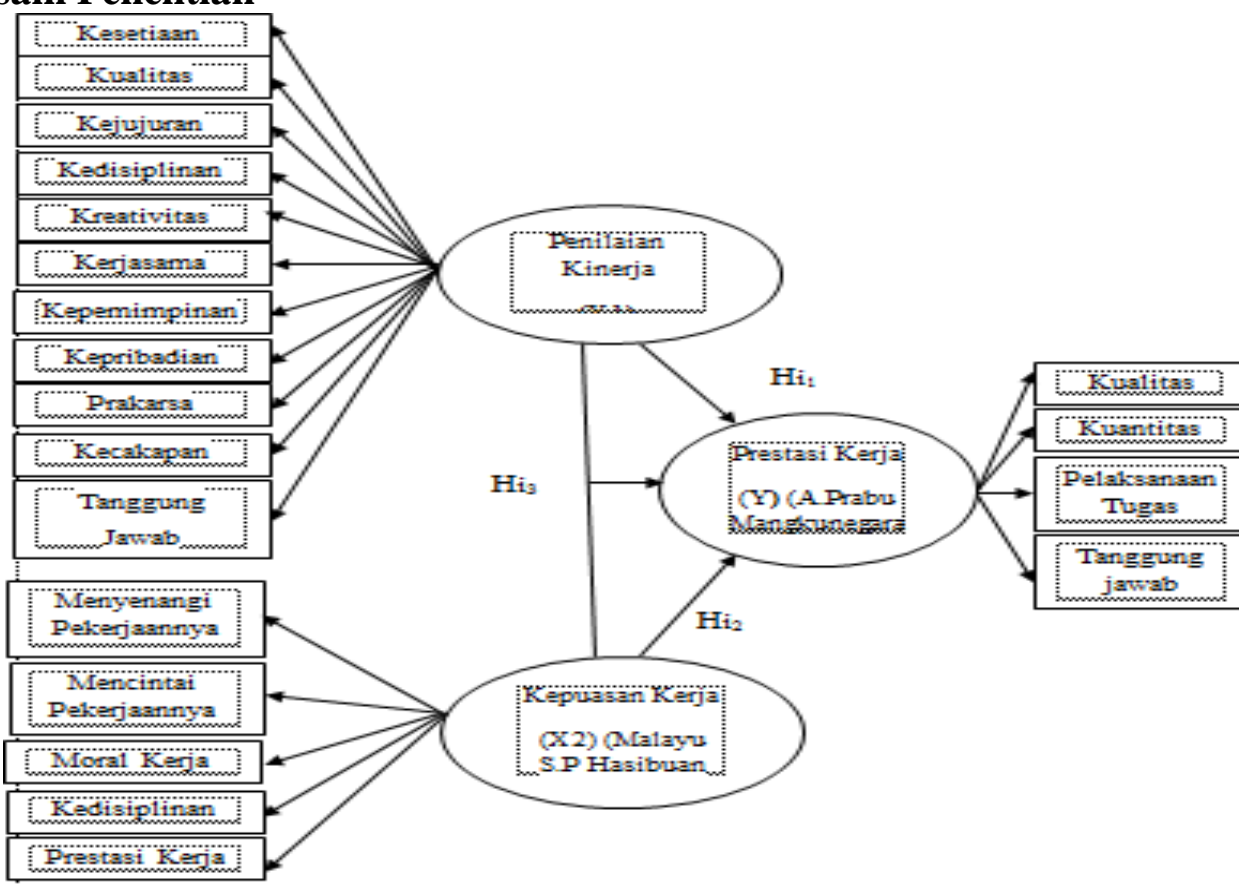

\section{Definisi Operasional Variabel Penelitian}

Sebelum mengadakan penilaian dalam penelitian, penulis harus menentukan operasionalisasi variabel. Hal ini bermaksud agar dapat mempermudah dalam melakukan penelitian. Variable penelitian ini terdiri atas variable Penilaian Kinerja (X1), Kepuasan Kerja (X2) dan Prestasi Kerja (Y).

Penilaian kinerja menurut Sedarmayanti (2011:261) adalah sistem formal untuk memeriksa/mengkaji dan mengevaluasi secara berkala kinerja seseorang. Indikator yang mempengaruhi penilaian kinerja karyawan menurut Hasibuan (2012) adalah sebagai berikut : (1) Kesetiaan, (2) Kualitas, (3) 
Kejujuran, (4) Kedisiplinan, (5) Kreativitas, (6) Kerjasama, (7) Kepemimpinan, (8) Kepribadian, (9) Prakarsa, (10) Kecakapan dan (11) Tanggung Jawab.

Kepuasan kerja menurut Malayu S.P Hasibuan ( 2008 : 202 ) adalah sikap emosional yang menyenangkan dan mencintai pekerjaanya. Indikator yang mempengaruhi kepuasan kerja menurut Malayu S.P Hasibuan ( 2008 : 202 ) adalah sebagai berikut : (1) Menyenangi pekerjaannya, (2) Mencintai pekerjaannya, (3) Moral kerja, (4) Kedisiplinan dan (5) Prestasi kerja.

Prestasi kerja menurut Malayu S.P. Hasibuan (2008 : 94) adalah suatu hasil kerja yang dicapai seseorang dalam melaksanakan tugas-tugas yang dibebankan kepadanya yang didasarkan atas kecakapan dan kesungguhan serta waktu. Indikator yang mempengaruhi prestasi kerja menurut A. Prabu. Mangkunegara (2009 : 67) adalah sebagai berikut : (1) Kualitas, (2) Kuantitas, (3) Pelaksanaan Tugas dan (4) Tanggung Jawab. Berikut tabel deskriptif operasional dan instrument variabel penelitian:

Deskriptif Operasional Dan Instument Variable Penelitian

\begin{tabular}{|c|c|c|}
\hline Variabel & Instrumen/Dimensi & Keterangan/Penjelasan atas instrumen variable \\
\hline \multirow{9}{*}{$\begin{array}{c}\text { Penilai } \\
\text { an } \\
\text { kinerja } \\
\text { karyaw } \\
\text { an (X1) } \\
\text { (Hasibu } \\
\text { an } \\
2012 \text { ) }\end{array}$} & 1. Kesetiaan & $\begin{array}{l}\text { Mencerminkan kesediaan karyawan menjaga dan } \\
\text { membela organisasi di dalam maupaun di luar } \\
\text { pekerjaan }\end{array}$ \\
\hline & 2. Prestasi Kerja & $\begin{array}{l}\text { Hasil kerja baik kualitas maupun kuantitas yang } \\
\text { dapat dihasilkan karyawan tersebut dari uraian } \\
\text { pekerjaannya }\end{array}$ \\
\hline & 3. Kejujuran & $\begin{array}{l}\text { Kejujuran dalam melaksanakan tugas-tugas } \\
\text { memenuhi perjanjian baik bagi diri sendiri maupun } \\
\text { orang lain }\end{array}$ \\
\hline & 4. Kedisiplinan & $\begin{array}{l}\text { Mencerminkan kepatuhan karyawan dalam } \\
\text { mematuhi peraturan yang ada dalam melakukan } \\
\text { pekerjaan sesuai dengan instruksi yang diberikan } \\
\text { kepadanya }\end{array}$ \\
\hline & 5. Kreativitas & $\begin{array}{l}\text { Kemampuan karyawan dalam mengembangkan } \\
\text { kreativitasnya untuk menyelesaikan pekerjaaanya, } \\
\text { sehingga lebih berdaya guna dan hasil guna }\end{array}$ \\
\hline & 6. Kerjasama & $\begin{array}{l}\text { Kesediaan karyawan berprestasi dan bekerja sama } \\
\text { dengan karyawan lain secara vertikal dan horizontal } \\
\text { didalam maupun diluar pekerjaannya }\end{array}$ \\
\hline & $\begin{array}{l}\text { 7. Kepemimpina } \\
\mathrm{n}\end{array}$ & $\begin{array}{l}\text { Kemampuan untuk memimpin, berpengaruh, } \\
\text { mempunyai pribadi yang kuat, dihormati, berwibawa } \\
\text { dan dapat memotivasi orang lain atau bawahan untuk } \\
\text { berkerja secara efektif. }\end{array}$ \\
\hline & 8. Kepribadian & $\begin{array}{l}\text { Sikap perilaku, kesopanan, periang, memberikan } \\
\text { kesan yang menyenangkan, memperhatikan sikap } \\
\text { yang baik, serta berpenampilan simpatik dan wajar }\end{array}$ \\
\hline & 9. Prakarsa & $\begin{array}{l}\text { Kemapuan berpikir yang original dan berdasarkan } \\
\text { inisiatif sendiri unutk menganalisis, menilai, } \\
\text { menciptakan, memberikan alasan dan mendapatkan }\end{array}$ \\
\hline
\end{tabular}




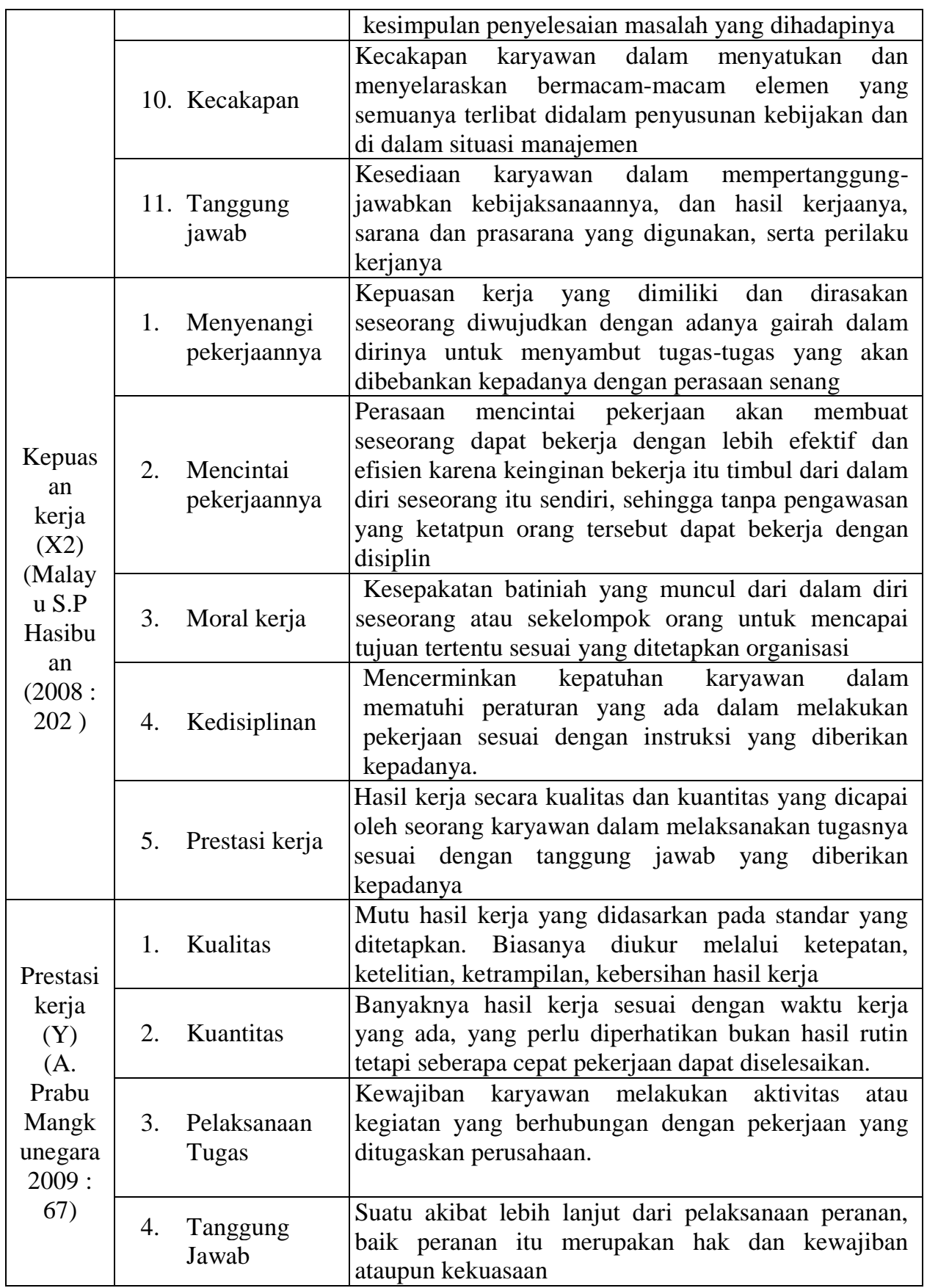

\section{Populasi Dan Sampel}

Populasi penelitian ini adalah seluruh karyawan PT. Mitrapak Eramandiri Cabang Cikarang sebanyak 134 karyawan. Sampel Pemilihan dilakukan dengan menggunakan metode sample acak (random sampling) dengan penarikan sample menggunakan rumus Slovene. Presentasi (10\%), kelonggaran toleransi ketidaktelitian karen kesalahan pengambilan sample. Berdasarkan rumus slovin 
diatas, maka jumlah sample adalah 57 Respondenyang mewakili populasi yang dipilih secara acak.

\section{Metode Pengumpulan Data}

Metode yang digunakan dalam penelitian ini adalah :

\section{Data Primer}

Merupakan data yang diperoleh langsung dari objek penelitian yaitu data yang diperoleh dari responden dengan mengajukan angket pada karyawan PT. Mitrapak Eramandiri Cabang Cikarang sebanyak 57 responden.

\section{Data Sekunder}

Data sekunder yang digunakan adalah buku-buku, literatur dan bacaan yang berkaitan dengan objek penelitian yaitu PT. Mitrapak Eramandiri Cabang Cikarang.

\section{Teknik Pengumpulan Data}

Teknik pengumpulan data penelitian ini adalah :

1. Observasi

Dilakukan dengan cara mengamati langsung kegiatan operasional ditempat melakukan penelitian untuk mengetahui pengaruh penilain kinerja dan kepuasan kerja terhadap prestasi kerja karyawan PT. Mitrapak Eramandiri Cabang Cikarang.

2. Studi Pustaka

Diperoleh dengan cara mempelajari dan pengumpulkan informasi melalui buku-buku referensi tentang pengaruh penilaian kinerja dan kepuasan kerja terhadap prestasi kerja karyawan.

3. Kuesioner

Dilakukan dengan cara memberikan kuesioner kepada beberapa karyawan dengan skala 5 pengukuran Likert.

\section{Metode Analisis Data}

Metode analisis data yang digunakan dalam penelitian ini adalah metode analisis statistic yang digunakan untuk menguji hipotesis yaitu dengan menggunakan SPSS Versi 22.

1. Uji Istrumen penelitian
a. Uji Validitas
b. Uji Reliabilitas

2. Uji Asumsi Klasik
a. Uji Normalitas
b. Uji Multikolonieritas
c. Uji Heteroskedastisitas

3. Analisis Regresi Linier Berganda

4. Koefisien Determinasi $\left(\mathrm{R}^{2}\right)$ 


\section{Uji Hipotesis}

a. Uji Signifikan Parameter Individu (Uji Statistik t)

b. Pengujian Hipotesis Secara Simultan (Uji F) 


\section{HASIL PENELITIAN}

\section{Karakteristik Responden Penelitian}

Data deskriptif yang menggambarkan keadaan atau kondisi responden perlu diperhatikan sebagai informasi tambahan untuk memehami hasil penelitian. Responden dalam penelitian ini yaitu sejumlah 57 karyawan dari total 134 karyawan. Data responden yang sudah dirinci berdasarkan jenis kelamin, pendidikan terakhir, masa kerja dan usia adalah sebagai berikut:

Responden berdasarkan jenis kelamin menyatakan bahwa jumlah pegawai pria sebanyak 41 orang $(71,9 \%)$ sedang pegawai wanita 16 orang $(28,1 \%)$. Hal tersebut menunjukkan bahwa jumlah pegawai pria di PT. Mitrapak Eramandiri Cabang Cikarang lebih banyak dari pada pegawai wanita: Responden berdasarkan pendidikan terakhir menyatakan bahwa pegawai lulusan D3 sebanyak 3 orang $(5,3 \%), \mathrm{S} 1$ sebanyak 7 orang $(12,3 \%)$ dan SMU sebanyak 47 orang $(82,5 \%)$. Hal tersebut menunjukkan bahwa mayoritas pegawai PT. Mitrapak Eramandiri Cabang Cikarang adalah lulusan SMU.

Berdasarkan lama responden bekerja, menyatakan bahwa pegawai yang lama kerjanya $1-2$ tahun ada 4 orang (7\%), $3-4$ tahun ada 18 orang $(31,6 \%), 5$ - 6 tahun ada 13 orang $(22,8 \%), 7$ - 8 tahun ada 13 orang (22,8\%), 9 - 10 tahun ada 9 orang (15,8\%). Hal ini menunjukkan bahwa mayoritas pegawai PT. Mitrapak Eramandiri Cabang Cikarang bekerja selama 3 - 4 tahun.

Berdasarkan usia, menyatakan bahwa pegawai yang memiliki usia $<25$ tahun ada 12 orang $(21,1 \%)$, usia 25 - 35 tahun ada 28 orang $(49,1 \%)$, usia 36 - 45 tahun ada 14 orang $(24,6 \%)$ dan usia 46 - 55 tahun ada 3 orang $(5,3 \%)$. Hal ini menunjukkan bahwa mayoritas pegawai PT. Mitrapak Eramandiri Cabang Cikarang memiliki usia 25 - 35 tahun.

\section{Pembahasan}

Uji validitas variabel penilaian kinerja karyawan, kepuasan kerja dan prestasi kerja karyawan. Hasil penelitian dari 57 orang responden tentang variable penilaian kinerja karyawan, kepuasan kerja dan prestasi kerja karyawan kemudian dilakukan uji korelasi untuk mengetahui seberapa besar $r$ hitung yang diperoleh dari pendapat mengenai indikator-indikatornya. Jumlah responden dalam uji validitas ini sebanyak 57 responden sehingga diperoleh nilai $r$ tabel $(0,2609)$ yang diperoleh dari tingkat kepercayaan $95 \%$ atau taraf signifikansi $5 \%$. Uji validitas ini dilakukan dengan membandingkan $r$ hitung lebih besar dari $r$ table $(0,2609)$. Apabila $r$ hitung bernilai positif, maka pernyataan tersebut dikatakan valid. Berikut hasil uji validitas penilaian kinerja karyawan, kepuasan kerja dan prestasi kerja karyawan :

\section{Variabel Penilaian Kinerja Karyawan}

Hasil uji validitas terhadap butir-butir pernyataan variabel penilaian kinerja karyawan, diketahui bahwa semua pernyataan dinyatakan valid karena memiliki nilai $r$ hitung $>r$ tabel sehingga butir pernyataan tersebut tetap digunakan dalam penelitian selanjutnya untuk mengukur penilaian kinerja karyawan. 


\section{Variabel Kepuasan Kerja}

Hasil uji validitas terhadap pernyataan variabel kepuasan kerja diketahui bahwa semua pernyataan dinyatakan valid karena memiliki nilai $r$ hitung $>r$ tabel sehingga butir pernyataan tersebut tetap digunakan dalam penelitian selanjutnya untuk mengukur kepuasan kerja.

\section{Variabel Prestasi Kerja Karyawan}

Hasil uji validitas terhadap butir-butir pernyataan variabel prestasi kerja karyawan, diketahui bahwa semua pernyataan dinyatakan valid karena memiliki nilai $r$ hitung $>r$ tabel sehingga butir pernyataan tersebut tetap digunakan dalam penelitian selanjutnya untuk mengukur prestasi kerja karyawan.

Uji reliabilitas variabel penilaian kinerja diperoleh koefisien Cronbach Alpha sebesar 0,620, variabel kepuasan kerja diperoleh koefisien Cronbach Alpha sebesar 0,731 dan variabel prestasi kerja diperoleh koefisien Cronbach Alpha sebesar 0,703. Nilai koefisien yang diperoleh dari ke tiga variabel lebih besar dari Cronbach Alpha yang disyaratkan, maka ke tiga variabel tersebut dinyatakan reliabel.

\section{Uji Asumsi Klasik}

\section{Uji Normalitas}

Dari analisis kurva dapat dilihat bahwa data menyebar di sekitar diagram dan mengikuti model regresi sehingga dapat disimpulkan bahwa data yang diolah merupakan data yang berdistribusi normal sehingga uji normalitas terpenuhi.

\section{Uji Multikolonieritas}

Uji multikolonieritas nilai tolerance variabel penilaian kinerja dan variabel kepuasan kerja sebesar 0,856 lebih besar dari 0,10. Sementara nilai VIF variabel penilaian kinerja dan variabel kepuasan kerja sebesar 1,168 lebih kecil dari 10,00. Jadi dapat disimpulkan bahwa tidak terjadi multikolinieritas antara variabel bebas penilaian kinerja dan variabel kepuasan kerja terhadap prestasi kerja.

\section{Uji Heteroskedastistas}

Sebaran titik-titik berada di atas dan di bawah angka nol pada sumbu Y dan tidak membentuk pola yang jelas, maka dapat disimpulkan tidak ada gejala heteroskedastisitas.

\section{Uji Regresi Linier Berganda}

Hasil pengolahan analisis regresi berganda dengan menggunakan software spss versi 22 adalah sebagai berikut:

Tabel 5.11

Hasil Uji Analisis Regresi Berganda

Coefficients $^{\mathbf{a}}$

\begin{tabular}{|l|c|c|c|c|}
\hline Model & $\begin{array}{c}\text { Unstandardized } \\
\text { Coefficients }\end{array}$ & $\begin{array}{c}\text { Standardized } \\
\text { Coefficients }\end{array}$ & $\mathrm{t}$ & Sig. \\
\cline { 2 - 5 }
\end{tabular}




\begin{tabular}{|ll|r|r|r|r|r|}
\hline & \multicolumn{1}{|c|}{ B } & Std. Error & \multicolumn{1}{|c|}{ Beta } & & \\
\hline 1 &, 759 & 5,438 & &, 139 &, 890 \\
& (Constant) &, 463 &, 111 &, 471 & 4,156 &, 000 \\
\cline { 2 - 8 } & Penilaian kinerja &, 463 &, 287 & 2,532 &, 014 \\
\cline { 2 - 7 } & Kepuasan kerja &, 274 &, 108 &, 2017 &
\end{tabular}

Sumber Data primer yang diolah, 2017

Berdasarkan tabel 5.11 perhitungan spss versi 22 tersebut diperoleh persamaan regresi linier berganda sebagai berikut :

$$
(\mathrm{Y})=0,759+0,463(\mathrm{X} 1)+0,274(\mathrm{X} 2)
$$

Penjelasan persamaan regresi linier berganda diatas adalah sebagai berikut:

1. Diperoleh nilai konstanta positif sebesar 0,759 , artinya jika nilai variabel penilaian kinerja dan variabel kepuasan kerja dianggap tidak ada atau sama dengan 0 , maka nilai prestasi kerja naik sebesar 0,759 .

2. Koefisien regresi untuk variabel bebas penilaian kinerja (X1) sebesar 0,463, artinya jika variabel independen lain nilainya tetap dan penilaian kinerja mengalami kenaikan 1 satuan maka prestasi kerja (Y) akan mengalami peningkatan sebesar 0,463 . Koefisien bernilai positif artinya terjadi hubungan antara penilaian kinerja dengan prestasi kerja, semakin naik penilaian kinerja maka semakin meningkat prestasi kerja.

3. Koefisien regresi untuk variabel bebas kepuasan kerja (X2) sebesar 0,274, artinya jika variabel independen lain nilainya tetap dan kepuasan kerja mengalami kenaikan 1 satuan, maka prestasi kerja (Y) akan mengalami peningkatan sebesar 0,274. Koefisien bernilai positif artinya terjadi hubungan antara kepuasan kerja dengan prestasi kerja, semakin naik kepuasan kerja maka semakin meningkat prestasi kerja.

\section{Koefisien Determinasi $\left(\mathbf{R}^{2}\right)$}

Koefisien determinasi pada intinya mengukur seberapa jauh kemampuan model dalam menerangkan variasi variabel.

Dengan menggunakan software SPSS versi 22 diperoleh koefisien determinasi sebagai berikut:

Tabel 5.12

Hasil Koefisien Determinasi $\left(\mathrm{R}^{2}\right)$

Model Summaryb

\begin{tabular}{|l|r|r|r|r|r|r|}
\hline & & & & & \multicolumn{2}{|c|}{ Change Statistics } \\
\cline { 6 - 8 } Model & & $\mathrm{R}$ & $\mathrm{R}$ & Square & Adjusted & Std. Error of \\
R Square & the Estimate & $\begin{array}{c}\text { R Square } \\
\text { Change }\end{array}$ & F Change \\
\hline 1 &, $637^{\mathrm{a}}$ &, 406 &, 384 & 1,61941 &, 406 & 18,484 \\
\hline
\end{tabular}

Sumber : Data primer yang diolah, 2017

Berdasarkan tabel 5.12 hasil analisis koefisien determinasi $\left(\mathrm{r}^{2}\right)$ pada kolom Adjusted $R$ Square menunjukan bahwa prosentase sumbangan pengaruh variabel independen (penilaian kinerja karyawan dan kepuasan kerja) terhadap variabel dependen (prestasi kerja karyawan) adalah 0,384 atau sebesar 38,4\%. Sedangkan 
sisanya sebesar $61,6 \%$ dipengaruhi oleh variabel lain yang tidak dimasukkan atau tidak dibahas dalam penelitian ini.

\section{Uji Hipotesis}

\section{Uji Signifikan Parameter Individu (Uji Statistik t)}

Hasil pengujian hipotesis secara parsial dengan menggunakan spss versi 22 adalah sebagai berikut :

Tabel 5.13

Hasil Uji Signifikan Parameter Individu (Uji Statistik t)

Coefficients $^{\mathbf{a}}$

\begin{tabular}{|c|c|c|c|c|c|c|}
\hline \multirow{2}{*}{\multicolumn{2}{|c|}{ Model }} & \multicolumn{2}{|c|}{$\begin{array}{c}\text { Unstandardized } \\
\text { Coefficients }\end{array}$} & \multirow{2}{*}{$\begin{array}{c}\text { Standardized } \\
\text { Coefficients } \\
\text { Beta }\end{array}$} & \multirow[b]{2}{*}{$\mathrm{t}$} & \multirow[b]{2}{*}{ Sig. } \\
\hline & & $\mathrm{B}$ & Std. Error & & & \\
\hline \multirow[t]{3}{*}{1} & (Constant) & ,759 & 5,438 & & , 139 &, 890 \\
\hline & Penilaian kinerja & ,463 &, 111 & ,471 & 4,156 &, 000 \\
\hline & Kepuasan kerja & 274 & ,108 & 287 & 2,532 & ,014 \\
\hline
\end{tabular}

Sumber Data primer yang diolah, 2017

Berdasarkan tabel 5.13 hasil uji signifikan parameter individu (uji statistik t) di atas pengambilan keputusan untuk hipotesis pertama variabel penilaian kinerja, diketahui bahwa regresi diperoleh nilai thitung sebesar 4,156 > t tabel 1,674 dan nilai signifikan (Sig.) $0,000<0,05$. Maka dapat disimpulkan bahwa Ho ditolak dan $\mathrm{Hi}_{1}$ diterima, yang artinya terdapat pengaruh signifikan penilaian kinerja (X1) terhadap prestasi kerja (Y).

Pengambilan keputusan untuk hipotesis kedua variabel kepuasan kerja, diketahui bahwa regresi diperoleh nilai t hitung sebesar 2,532 $>\mathrm{t}$ tabel 1,674 dan nilai signifikan (Sig.) 0,014<0,05. Maka dapat disimpulkan bahwa Ho ditolak dan $\mathrm{Hi}_{2}$ diterima, yang artinya terdapat pengaruh signifikan kepuasan kerja (X2) terhadap prestasi $\operatorname{kerja}(\mathrm{Y})$.

\section{Uji Hipotesis Secara Simultan (Uji F)}

Nilai df $(\mathrm{n} 1)=1$ dan df $(\mathrm{n} 2)=55$ serta taraf signifikan $5 \%$ atau 0,05 maka, didapat nilai $F$ tabel adalah 4,02. Hasil pengujian hipotesis secara simultan dengan menggunakan SPSS versi 22 adalah sebagai berikut :

Tabel 5.14

Uji Hipotesis Secara Simultan

ANOVA $^{\mathrm{a}}$

\begin{tabular}{|c|c|c|c|c|c|c|}
\hline \multicolumn{2}{|c|}{ Model } & $\begin{array}{l}\text { Sum of } \\
\text { Squares }\end{array}$ & $\mathrm{df}$ & $\begin{array}{l}\text { Mean } \\
\text { Square }\end{array}$ & $\mathrm{F}$ & Sig. \\
\hline \multirow[t]{3}{*}{1} & Regression & 96,947 & 2 & 48,474 & 18,484 &, $000^{\mathrm{b}}$ \\
\hline & Residual & 141,614 & 54 & 2,622 & & \\
\hline & Total & 238,561 & 56 & & & \\
\hline
\end{tabular}

a. Dependent Variable: Prestasi kerja

b. Predictors: (Constant), Kepuasan kerja, Penilaian kinerja

Sumber Data primer yang diolah, 2017 
Berdasarkan tabel 5.14 uji hipotesis secara simultan (uji F), diketahui bahwa koefisien uji f diperoleh sebesar $18,484>$ nilai $\mathrm{F}$ tabel sebesar 4,02 dan nilai signifikan $0,000<0,05$, dengan demikian dapat disimpulkan bahwa $\mathrm{Hi}_{3}$ diterima artinya secara bersama-sama penilaian kinerja dan kepuasan kerja berpengaruh signifikan terhadap prestasi kerja pada PT. Mitrapak Eramandiri Cabang Cikarang.

\section{Pembahasan Hasil Penelitian}

\section{Pembahasan Analisis Data Uji Validitas Dan Uji Reliabilitas}

Berdasarkan uji validitas dan uji reliabilitas pada variabel penilaian kineja karyawan, kepuasan kerja dan prestasi kerja karyawan yang telah dilakukan dengan menggunakan software SPSS versi 22 menghasilkan data sebagai berikut :

a. Uji validitas menghasilkan butir-butir pernyataan atau indikator bernilai positif dan lebih besar dari $r$ tabel. Pada uji validitas variabel penilaian kinerja karyawan, kepuasan kerja dan prestasi kerja karyawan dinyatakan valid.

b. Berdasarkan uji reliabilitas pada tabel 5.08 variabel penilaian kinerja karyawan, kepuasan kerja dan prestasi kerja karyawan menghasilkan koefisien Cronbach Alpha lebih besar dari 0.06.

\section{Pembahasan Uji Asumsi Klasik}

Berdasarkan uji asumsi klasik yang telah dilakukan dengan menggunakan software SPSS versi 22 menghasilkan data-data sebagai berikut :

a. Uji normalitas dengan analisis kurva dapat dilihat bahwa data menyebar di sekitar diagram dan mengikuti model regresi sehingga dapat disimpulkan bahwa data yang diolah merupakan data yang berdistribusi normal sehingga uji normalitas terpenuhi.

b. Uji multikolonieritas menghasilkan nilai tolerance variabel penilaian kinerja dan variabel kepuasan kerja sebesar 0,856 lebih besar dari 0,10 . Sementara nilai VIF variabel penilaian kinerja dan variabel kepuasan kerja sebesar 1,168 lebih kecil dari 10,00. Ini sesuai dengan teori Ghazali (2011:105) yaitu nilai Variance Inflation Factor (VIF) tidak lebih dari 10 dan nilai Tolerance (TOL) tidak kurang dari 0,10. Jadi dapat disimpulkan bahwa tidak terjadi multikolinieritas antara variabel bebas penilaian kinerja dan variabel kepuasan kerja terhadap prestasi kerja.

c. Uji Heteroskedastistas pada diketahui bahwa sebaran titik-titik berada di atas dan di bawah angka nol pada sumbu Y dan tidak membentuk pola yang jelas, maka dapat disimpulkan tidak ada gejala heterosdaktisitas.

\section{Pembahasan Uji Regresi Linier Berganda}

Diperoleh persamaan regresi linier berganda yaitu $(Y)=0,759+$ $0,463(\mathrm{X} 1)+0,274(\mathrm{X} 2)$ dengan penjelasan sebagai berikut : 
a. Nilai konstanta positif sebesar 0,759, artinya jika nilai variabel penilaian kinerja dan variabel kepuasan kerja dianggap tidak ada atau sama dengan 0 , maka nilai prestasi kerja naik sebesar 0,759 .

b. Regresi untuk variabel bebas penilaian kinerja (X1) sebesar 0,463 artinya jika variabel independen lain nilainya tetap dan penilaian kinerja mengalami kenaikan 1\%, maka prestasi kerja (Y) akan mengalami peningkatan sebesar 0,463. Koefisien bernilai positif artinya terjadi hubungan antara penilaian kinerja dengan prestasi kerja, semakin naik penilain kinerja maka semakin meningkat prestasi kerja.

c. Koefisien regresi untuk variabel bebas kepuasan kerja (X2) sebesar 0,274, artinya jika variabel independen lain nilainya tetap dan kepuasan kerja mengalami kenaikan 1\%, maka prestasi kerja (Y) akan mengalami peningkatan sebesar 0,274. Koefisien bernilai positif artinya terjadi hubungan antara kepuasan kerja dengan prestasi kerja, semakin naik kepuasan kerja maka semakin meningkat prestasi kerja.

\section{Pembahasan Koefisien Determinasi $\left(\mathbf{R}^{2}\right)$}

Berdasarkan pada tabel 5.12 uji koefisien determinasi $\left(\mathrm{r}^{2}\right)$ diperoleh analisis koefisien determinasi $\left(\mathrm{r}^{2}\right)$ menunjukan bahwa prosentase sumbangan pengaruh variabel independen (penilaian kinerja karyawan dan kepuasan kerja ) terhadap variabel dependen (prestasi kerja karyawan) adalah sebesar adalah 0,384 atau sebesar 38,4\%. Sedangkan sisanya sebesar $61,6 \%$ dipengaruhi oleh variabel lain yang tidak dimasukkan atau tidak dibahas dalam penelitian ini.

\section{Pembahasan Uji Hipotesis}

a. Uji Signifikan Parameter Individu (Uji Statistik t) Pengaruh Penilaian Kinerja Karyawan Terhadap Prestasi Kerja Pada PT. Mitrapak Eramandiri Cabang Cikarang

Berdasarkan tabel 5.13 hasil uji signifikan parameter individu (uji statistik t), diketahui bahwa regresi diperoleh nilai t hitung sebesar 4,156 > t tabel 1,674 dan nilai signifikan (Sig.) 0,000 < 0,05. Maka dapat disimpulkan bahwa Ho ditolak dan $\mathrm{Hi}_{1}$ diterima, yang artinya terdapat pengaruh signifikan penilaian kinerja terhadap prestasi kerja karyawan pada PT. Mitrapak Eramandiri Cabang Cikarang.

Hasil penelitian ini didukung dengan hasil penelitian oleh Surya Rachma Aditya Eka Putra.,et al, Pengaruh Penilaian Kinerja Terhadap Prestasi Kerja Karyawan (Studi Pada Karyawan Bagian Produksi CV. Shuttlecock Nasional Kepanjen Malang), Vol.3 No.1, tahun 2015, dengan hasil penelitian nilai (sig) $\mathrm{F}<\alpha$ yaitu $0,000<0,05$ serta nilai Adjusted $R$ Square menunjukan angka sebesar 34,636 yang berarti bahwa variabel tersebut memberikan kontribusi sebesar 0,733 terhadap variabel prestasi kerja. Berdasarkan perhitungan tersebut, dapat disimpulkan bahwa secara parsial penilaian kinerja memiliki pengaruh signifikan terhadap prestasi kerja karyawan. 
b. Uji Signifikan Parameter Individu (Uji Statistik t) Pengaruh Kepuasan Kerja Terhadap Prestasi Kerja Pada PT. Mitrapak Eramandiri Cabang Cikarang

Berdasarkan tabel 5.13 hasil uji signifikan parameter individu (uji statistik $\mathrm{t}$ ), diketahui bahwa regresi diperoleh nilai $\mathrm{t}$ hitung sebesar 2,532 > t tabel 1,674 dan nilai signifikan (Sig.) 0,014<0,05. Maka dapat disimpulkan bahwa Ho ditolak dan $\mathrm{Hi}_{2}$ diterima, yang artinya terdapat pengaruh signifikan kepuasan kerja terhadap prestasi kerja karyawan pada PT. Mitrapak Eramandiri Cabang Cikarang.

Hasil penelitian ini didukung dengan hasil penelitian oleh Rina Milyati Yuniastuti, Analisis Pengaruh Kepuasan Kerja Terhadap Prestasi Kerja Karyawan Pada CV. Organik Agro System Di Bandar Lampung, Vol 1 No.2 : 199-210 tahun 2011, berdasarkan hasil perhitungan $r$ hitung $0,815>r$ tabel 0,396 pada tingkat kepercayaan 95\%, Dengan demikian dapat disimpulkan bahwa hipotesis penelitian yang menyatakan bahwa kepuasan kerja berpengaruh signifikan terhadap prestasi kerja karyawan pada CV. Organik Agro System (OASIS).

c. Uji hipotesis Secara Simultan (Uji F) Pengaruh Penilaian Kinerja Karyawan Dan Kepuasan Kerja Terhadap Prestasi Kerja Pada PT. Mitrapak Eramandiri Cabang Cikarang

Berdasarkan tabel 5.14 uji hipotesis secara simultan (uji F), diketahui bahwa koefisien uji $\mathrm{F}$ diperoleh sebesar 18,484> nilai $\mathrm{f}$ tabel sebesar 4,02 dan nilai signifikan $0,000<0,05$, dengan demikian dapat disimpulkan bahwa $\mathrm{Hi}_{3}$ diterima artinya secara bersama-sama penilaian kinerja dan kepuasan kerja berpengaruh signifikan terhadap prestasi kerja pada PT. Mitrapak Eramandiri Cabang Cikarang.

Hasil penelitian ini didukung dengan hasil penelitian oleh Cindi Ismi Januari.,et al, dengan judul penelitian "Pengaruh Penilaian Kinerja Terhadap Kepuasan Kerja dan Prestasi Kerja (Studi Kasus PT. Telekomunikasi Indonesia, Tbk Wilayah Malang)" yang dipublikasikan di Jurnal Administrasi Bisnis (JAB) Vol. 24 No. 2, 2015, berdasarkan hasil analisis jalur, dapat diketahui bahwa variabel penilaian kinerja dan kepuasan kerja berpengaruh signifikan terhadap prestasi kerja dengan nilai signifikan sebesar 0,000.

\section{KESIMPULAN}

Berdasarkan hasil pengujian yang telah dilakukan, maka dapat disimpulan sebagai berikut :

1. Hasil pengujian secara parsial penilaian kinerja karyawan berpengaruh positif dan signifikan terhadap prestasi kerja karyawan dengan nilai $t_{\text {hitung }}$ $4,156>t_{\text {tabel }} 1,674$.

2. Hasil pengujian secara parsial kepuasan kerja berpengaruh positif dan signifikan terhadap prestasi kerja karyawan dengan nilai thitung 2,532 > $t_{\text {tabel }} 1,674$. 
3. Hasil pengujian secara simultan penilaian kinerja karyawan dan kepuasan kerja bersama-sama berpengaruh terhadap prestasi kerja karyawan dengan nilai $F_{\text {hitung }} 18,484>F_{\text {tabel }} 4,02$.

Berikut adalah saran yang diajukan untuk perusahaan dan peneliti selanjutnya :

1. Hasil penelitian ini menunjukan bahwa penilaian kinerja karyawan dan kepuasan kerja memiliki pengaruh positif terhadap prestasi kerja karyawan, sehingga apabila perusahaan ingin meningkatkan prestasi kerja karyawan maka penilaian kinerja karyawan dan kepuasan kerja perlu ditingkatkan.

2. Untuk peneliti mendatang agar menambah variabel yang mempengaruhi prestasi kerja misalnya motivasi kerja.

3. Penulis hanya meneliti dengan sampel 57 karyawan. Untuk peneliti mendatang agar mengambil sampel seluruh karyawan.

\section{REFERENSI}

Alfian, G., 2012. Pengaruh Kepemimpinan Terhadap Kepuasan Kerja Dan Produktivitas Kerja Karyawan Pada PT. Taspen (Persero) Cabang Yogyakarta (Doktoral Dissertastion, Universitas Negeri Yogyakarta). Eprint.uny.ac.id/7518/. (Diakses 20 Agustus 2017)

Ariani, D., et al., 2013. Pengaruh Kepuasan Kerja Dan Motivasi Kerja Terhadap Prestasi Kerja Karyawan (Studi Pada PT. Inti Luhur Fuja Abadi (ILUFA), Pasuruan). Jurnal Administrasi Bisnis, 1(1), pp.123-131. http://administrasibisnis.studentjournal.ub.ac.id/index.php/jab/article/view/17. (Diakses 18 Juni 2017 pukul 15.16 wib.)

Arif Bintara, Alfian. 2014. Penelitian Deskriptif Kuantitatif, Penelitian Korelasi, Dan Penelitian Ekspos-Fakto.

https://pangeransastra.wordpress.com/2014/10/13/penelitian-deskriptifkuantitatif-penelitian-korelasi-dan-penelitian-ekspos-fakto/. (Diakses $\quad 7 \quad$ Juli 2017)

Aznira, Z., 2014. Pengaruh kepuasan kerja terhadap prestasi kerja: Satu kajian ke atas ejen penghantaran di Kompleks Kastam Bukit Kayu Hitam (Doctoral dissertation, Universiti Utara Malaysia). http://etd.uum.edu.my/4048/2/s813287 abstract.pdf. (Diakses 18 Juni 2017 pukul 15.28 wib.)

Bayu Kresna S, Moch. 2016. Pengaruh Kompetensi, Motivasi, Dan Kepuasan Kerja Terhadap Prestasi Kerja Sales Promotion Lembaga Rumah Sehat Indonesia. https://simki.lp2m.unpkediri.ac.id/mahasiswa/file artikel/2016/11.1.02.02.0058. pdf. (Diakses 18 Juni 2017 pukul 15.42 wib.)

Dwipayana, A.D., Supartha, W.G. and Sintaasih, D.K., 2016. Penerapan Sistem Penilaian Kinerja; Dampaknya Terhadap Kepuasan Dan Stres Kerja Karyawan. E-Jurnal Ekonomi dan Bisnis Universitas Udayana, 4(10). https://ojs.unud.ac.id/index.php/EEB/article/view/14188. (Diakses 7 Juni 2017)

Eka, D., 2015. Pengaruh Penilaian Kinerja Dan Disiplin Kerja Terhadap Prestasi Kerja Karyawan Pada PT. Bank Syariah Mandiri Cabang Banjarmasin. http://idr.iain-antasari.ac.id/171/. (Diakses 18 Juni 2017 pukul 14.22 wib.)

Ghozali, Imam. (2011). Aplikasi Analisis Multivariate dengan Program SPSS. Badan Penerbit Universitas Diponogoro:Semarang. 
Hasibuan, Malayu. (2008). Manajemen Sumber Daya Manusia. Bumi Aksara: Jakarta

Iqbal, N.,et al., 2013. Impact of performance appraisal on employee's performance involving the moderating role of motivation. Oman Chapter of Arabian Journal of Business and Management Review, 3(1), pp.37-56. https://www.arabianjbmr.com/pdfs/OM_VOL_3_(1)/4.pdf. (Diakses 23 Juli 2017)

Januari, C.I., et al, 2015. Pengaruh penilaian kinerja terhadap kepuasan kerja dan prestasi kerja (studi pada karyawan pt. telekomunikasi indonesia, tbk wilayah malang). Jurnal Administrasi Bisnis, 24(2). http://administrasibisnis.studentjournal.ub.ac.id/index.php/jab/article/viewFile/9 68/1150. (Diakses 5 Juli 2017 pukul 20.16 wib.)

Khan, A.H., Nawaz, M.M., Aleem, M. and Hamed, W., 2012. Impact of job satisfaction on employee performance: An empirical study of autonomous Medical Institutions of Pakistan. African Journal of Business Management, 6(7), p.2697. http://www.academicjournals.org/AJBM. (Diakses 23 Juli 2017 pukul 14.54 wib.)

Kusdyah Rachmawati, Ike. (2008). Manajemen Sumber Daya Manusia. CV. Andi Offset:Yogyakarta

Maharani, Vivin., et al., 2013. Organizational Citizenship Behavior Role in Mediating the Effect of Transformational Leadership, Job Satisfaction on Employee Performance: Studies in PT Bank Syariah Mandiri Malang East Java. International Journal of Business and Management. 8(17). http://www.ccsenet.org/journal/index.php/ijbm/article/view/27599/17557.

(Diakses 12 Agustus 2017)

Prabu Mangkunegara, Anwar. (2011). Manajemen Sumber Daya Manusia Perusahaan. PT. Remaja Rosdakarya:Bandung.

Prasetiyo, Fandi. 2014. Teori-teori prestasi kerja. http://fandiprasetiyo.blogspot.co.id/2014/02/teor-teori-prestasi-kerja.html. (Diakses 7 Juni 2017)

Putra, S.R.A.E., 2015. Pengaruh Penilaian Kinerja Terhadap Prestasi Kerja Karyawan (Studi pada Karyawan Bagian Produksi CV. Shuttlecock Nasional Kepanjen Malang). Jurnal Administrasi Bisnis, 20(1). http://administrasibisnis.studentjournal.ub.ac.id/index.php/jab/article/view/818. (Diakses 5 Juli 2017 pukul 19.19 wib.)

Putri, N. and Zulkarnia, A., 2015. Pengaruh Kepuasan Kerja Dan Disiplin Kerja Terhadap Prestasi Kerja Karyawan Pada Pt Daya Kobelco Construction Machinery Indonesia Cabang Palembang (Doctoral dissertation, Politeknik Negeri Sriwijaya). http://eprints.polsri.ac.id/2433/. (Diakses 18 Juni 2017 pukul 15.31 wib.)

Olusola, O., 2011. Intinsic Motivation, Job Satisfaction And Self-Efficacy As Predictors Of Job Performance Of Industrial Workers In Ijebu Zone Of Ogun State. Journal of international social research, 4(17). http://www.sosyalarastirmalar.com/cilt4/sayi17pdf/5egitim/olusola_olayiwola.p df . (Diakses 22 Agustus 2017 pukul 00.26 wib.)

Sajati, Kanzi. 2016. Manajemen Sumber Daya Manusia. https://orygom.blogspot.co.id/2016/04/manajemen-sumber-daya-manusia.html.

(Diakses 16 Juli 2017)

Suprihatiningrum, H. and Bodroastuti, T., 2012. Faktor-Faktor Yang Mempengaruhi Prestasi Kerja (Studi Pada Karyawan Kantor Kementrian Agama Provinsi Jawa Tengah). Jurnal Kajian Akuntansi dan Bisnis, 1(1). http://jurnal.widyamanggala.ac.id/index.php/wmkeb/article/view/65. (Diakses 21 Agustus 2017 pukul 21.10 wib.)

Sutrisno, Hadi. (2009). Manajemen Sumber Daya Manusia. Andi Offset: Yogyakarta. 
Suwarno. 2014. Pengaruh Motivasi Dan Penilaian Kerja Terhadap Prestasi Kerja Pegawai Pada Kantor Camat Sumber Harta Kabupaten Musi Rawas. Jurnal

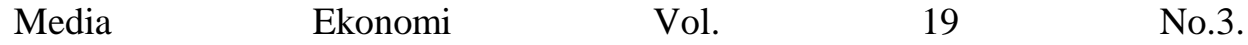
http://stie.muralinggau.ac.id/files/JME/Volume\%2019\%2C\%20Nomor\%203\%2 C\%20Desember\%202014/2suwarno.pdf. (Diakses 5 Juli 2017 pukul 19.24 wib.)

Tapip Yani, Asep. (2011). Manajemen Sumber Daya Manusia. Humaniora: Bandung.

Triana Siregar. Neni, dan Suryalena. 2017. Pengaruh penilaian kinerja karyawan dan reward terhadap prestasi kerja karyawan pada hotel sapadia Pasir pengaraian. Jurnal Online Mahasiswa. Vol. 4 No. 2. https://jom.unri.ac.id/index.php/JOMFSIP/article/view/14510/0. (Diakses 5 Juli 2017 pukul 19.42 wib.)

Tanjung, Vina. 2013. Teori Tentang Prestasi Kerja Karyawan. http://bloggerviens.blogspot.co.id/2013/01/prestasi-kerja.html. (Diakses 7 Juni 2017)

Tony, Adam. 2012. Penilaian Kerja (Performance Appraisal. http://rokokdankorek.blogspot.co.id/2012/12/penilaian-kerja-performanceappraisal.html. (Diakses 13 Maret 2017 pukul 21:34 wib.)

Yuniastuti, R.M., 2011. Analisis pengaruh Kepuasan Kerja terhadap Prestasi Kerja Karyawan CV. Organik Agro System (OASIS) Bandar Lampung. Jurnal Organisasi dan Manajemen, 1(1), pp.35-40. http://jurnal.ubl.ac.id/index.php/jmb/article/view/44. (Diakses 18 Juni 2017 pukul 15.07 wib.)

Wahyuningsih, E.P., 2012. Hubungan Antara Kepuasan Kerja Dengan Prestasi Kerja Karyawan Di Pt. Solo Murni Cabang Boyolali (Doctoral dissertation, Universitas Muhammadiyah Surakarta). http://eprints.ums.ac.id/18270/2/BAB_I.pdf. (Diakses 18 Juni 2017 pukul 15.25 wib.) 